\title{
Which way forward for East Asian regional integration? - CGE Model Analysis
}

\author{
Inkyo Cheong*and Min Ha Lee**
}

\begin{abstract}
Among various distinctive formulations that have been developed simultaneously in East Asia as of 2009, this paper selected three major paths, ASEAN+3, ASEAN+6 and APEC, to quantitatively examine the economic impacts of Asian regionalization with the CGE model. This paper confirmed previous findings such as the magnitude of economic impact being proportional to the size of membership and the existence of trade diversion effect within all trade blocs. The subsequent KORUS and Korea-EU FTA imposition upon the built CGE base models further verified the effects of hub-and-spoke-ism in East Asia. Jointly, the simulation results implied that the economic impacts of a trade arrangement heavily depend on the subject economy's reliance on trade with the participating states. It was also found that the impacts were directly proportional to the accrued trade balance of the subject spoke country with both the hub state and the hub-destination. This could have been exaggerated as the scope of this study was limited to East Asia where KORUS FTA was found to be more influential than Korea-EU FTA due to its exceptionally high reliance on the US. On the course of this research to verify the aforementioned findings, however, both GTAP 6 and 7 were adopted, and hence, the economic impacts of China's accession to the WTO in the global trade system were also empirically proven.
\end{abstract}

Keywords: East Asian regionalization, ASEAN+3, ASEAN+6, APEC, FTA, CGE analysis.

Submission Date: 11/16/2009

Revision Date: 12/11/2009

Acceptance Date: 12/11/2009

* Corresponding Author, Director, Jungseok Research Institute of International Logistics and Trade, Professor, College of Economics and International Trade, Inha University. 253 Yonghyun-Dong, Nam-Gu, Incheon, Korea. Tel: +82 32860 7785. E-mail: inkyo@inha.ac.kr

** First Author, Researcher, Korea National Center for APEC Studies, Dept. of Trade and Investment Policy. Korea Institute for International Economic Policy(KIEP). Korea. Tel: +82 23460 1031. E-mail: impminha@naver.com 


\section{Introduction}

The most evident changes made for the trade environment in East Asia since the 1997 Asian Financial Crisis are undeniably the proliferation of preferential trade agreements (PTAs), typically bilateral free trade agreements (FTAs). Ironically, however, not many have been de facto effectuated among a number of intra- and inter-regional trade agreements concluded by East Asian countries despite a high number of positive forecasts on trade liberalization in the region. One of the popular explanations offered for this large gap between theory and practice is the traditional devotion of key East Asian countries, namely Japan and Korea, in the multilateral trade liberalization schemes. The logic goes that because all the economic powers in Asia (Japan plus the Four Asian Tigers ${ }^{1}$ ) have obtained current status greatly owing to the open trade environment, Asia as a whole region tends to remain loyal to the GATT/WTO regime in preference of globalization over regionalization.

The nature of regionalism reflected in such behavior basically is the discrimination of any kinds of PTAs on the non-members while the core objective of the multilateral trading system under the WTO is 'the elimination of discriminatory treatment in international trade relations.' 2 Yet, because the impact of a PTA varies significantly in accordance with the size, scope and the balance of preferences conferred amongst the signing parties while the economic benefits or losses of maintaining PTA networks alongside multilateral rules has not been determined numerically, PTAs have been specified as the exceptions to the general Most Favored Nations treatment of the WTO. ${ }^{3}$ Instead, so as to control the complexity of a simultaneous processing of these two contradicting modes of international trade liberalization, the WTO agreements have evolved to contain conditions for PTAs to be verified under the WTO regime. ${ }^{4}$

Particularly, the recent EC-Tariff Preferences case induced the first ruling of the Appellate Body (AB) on the justification of PTAs. The report quoted Article XXIV:5 of GATT 1994, which provides an exception to certain WTO obligation for custom unions and free-trade agreements (FTAs), the two typical modes of PTAs as defined in Article XXIV:8(a) and (b) respectively, and explained that the wordings were chosen so as the provisions of the GATT 1994 "shall not make impossible" the formation of a customs union or an FTA. ${ }^{5}$ This, in turn, established the nexus between Article XXIV:5 and PTAs in

\footnotetext{
1 Four Asian Tigers refers to the four newly industrialized economies of Hong Kong, Korea, Singapore and Taiwan who have displayed exceptionally high growth rates and rapid industrialization between the early 1960s and 1990s.

2 WTO Agreement, Preamble

3 GATT 1994, Article XXIV; GATS, Article V

4 Enabling Clause, paragraph 2(c), as a decision of the GATT CONTRACTING PARTIES, the Enabling Clause forms part of GATT 1994: see para 1(b)(iv) of the language incorporating GATT 1994 into the WTO Agreement.

5 Article XXIV:5 states that, accordingly, the provisions of this Agreement shall not prevent, as between the
} 
principle to justify and defend its inconsistency with GATT 1994. What is noteworthy, however, is that none have completed the examination process and found WTO-consistent among 205 WTO reported PTAs as of June 2008, since its establishment in 1995. ${ }^{6}$ Hence, and in accordance with the general jurisprudence of WTO regarding the burden of proof in disputes, the Party challenging a PTA should establish its inconsistency with a provision of GATT 1994 while the responding Member is to prove its inclusion in Article XXIV:5.7 As such, the complexity of having two contradicting modes simultaneously has, inevitably, aroused concerns for systemic risk. Naturally, hence, the WTO, in a pursuit of an idealistic international trade environment, urges the involved countries to design PTAs in the shape of stepping stones towards a freer global trading and investment environment ${ }^{8}$ through which the WTO+ agreements can induce otherwise difficult domestic structural reforms.

Accordingly, East Asia ${ }^{9}$ has quickly adopted to the changing global trade environment, as reflected in the aforementioned proliferating PTAs since 1997, to develop three possible scenarios simultaneously towards East Asian regionalization: ASEAN+3,10 ASEAN+611 and APEC FTAs12. The parallel development of these three options has caused major confusion in designing the integration blueprints for the region that demand 'choice and concentration of regional capacity' and became one of the key issues on the agenda at the 2009 APEC Study Centers Consortium Conference held in July in Singapore. Under these combined circumstances of a PTA proliferating world economy and East Asia as the last trade bloc-free region, this paper proposes to quantitatively, using CGE model analysis as a tool, evaluate the pros- and cons- of the three existing options (ASEAN+3, ASEAN+6 and APEC FTAs).

Before doing so, however, two key terminologies to be clarified for better

territories of Members, the formation of a customs union or of a free-trade area or the adoption of an interim agreement necessary for the formation of a customs union or of a free trade area, provided that conditions identified in para (a) to (c) are successfully satisfied.

6 http://www.wto.org/english/tratop_e/region_e/region_e.htm

7 Appellate Body Reports of Turkey-Textiles (para 45), EC-Tariff preferences (100-103) and US-Wool Shirts and Blouses (14) against EC-Tariff Preferences (paras 87-88).

8 Chia Siow Yue (August, 2007)

${ }^{9}$ East Asia, for the purpose of this paper, is defined as ASEAN+3 countries.

10 Refers to The Association of Southeast Asian Nations, launched in August, 1967 (Indonesia, Malaysia, the Philippines, Singapore, Thailand, Brunei, Cambodia, Laos, Myanmar and Vietnam), plus three Northeast Asian countries (China, Japan and Korea).

11 Refers the 16 members of East Asian Summit (EAS), launched in December 2005, which includes 10 ASEAN countries, 3 Northeast Asians and 3 more elsewhere - India (Asia), Australia (Oceania) and New Zealand (Oceania).

12 Abbreviation for Asia-Pacific Economic Cooperation, now a forum for 21 Pacific Rim countries of Australia, Brunei, Canada, Chile, China, Hong Kong China, Chinese Taipei, Indonesia, Japan, Korea, Malaysia, Mexico, New Zealand, Papua New Guinea, Peru, the Philippines, Russia, Singapore, Thailand, the US and Vietnam, that was originally established to promote open regionalism through voluntary unilateral and concerted liberalization of trade and investment in 1989. 
understanding are regionalization and hub-and-spoke-ism. The first term is critical in understanding the current status of the East Asian regionalization process because that is what East Asia has pursued so far, which contrasts from the regionalism widely spread in Europe. So as to clearly distinguish this difference, the author defines the term regionalism, in accordance with recent academic research, as the political process in which more than two states drive cooperative initiatives. On the contrary, the term regionalization will be linked to the processes of economic integration among more than two states which, while state policies remain highly influential, are essentially the uncoordinated consequence of private sector activities. ${ }^{13}$ Globalization, in this regard, will denote any inter-regional, both bilateral and multilateral, economic integration processes. The remaining bilateral intra-regional cooperation will be titled partnership, while the term integration process is a generic name to collectively address the various cooperation processes listed above.

Amid the regionalization process in East Asia, ASEAN has signed three independent ASEAN +1 trade agreements with China, Japan and Korea, while the negotiations among the three Northeast Asian countries are on halt for various reasons. Such progress, in hands with the political economic force that drives the domino effect on the proliferation of FTA in the region, could be seen as rather unfortunate because of its likelihood to invite hub-and-spoke bilateralism in the region. ${ }^{14}$ In this regard, this paper intends to quantitatively analyze the mal effect of hub-and-spoke-ism, 15 what is known as the most undesirable form of economic integration, by introducing five additional scenarios upon the pre-established three base options of ASEAN+3, ASEAN+6 and APEC FTAs.

\section{CGE Analysis on East Asian Regionalization}

In order to quantitatively analyze the regionalization effects in East Asia by comparing them among the three basic options of ASEAN+3, ASEAN+6 and APEC FTAs as proposed, this paper adopted the CGE model, the most commonly encountered quantitative analytical technique in the area of trade. It is a powerful tool for analyzing the economic effects of FTAs having its basis on a clear economy-wide theoretical structure embodying a general equilibrium condition. Simply, the CGE analysis results provide insights into the numerical magnitude of gains and losses from trade liberalization and the distribution across regions, countries and sectors. In this light, the main benefit of CGE models is that they offer a rigorous and theoretically consistent framework for analyzing trade policy questions. The numbers obtained from the simulations should only be used in relative terms to compare the

\footnotetext{
13 Breslin and Higgott (2000)

14 Wonnacott(1996) has theoretically proved that a region-wide FTA is more advantageous than a hub-and-spoke system in various aspects.

$15 \mathrm{~A}$ word taken from a chariot wheel to refer to a trade system in which all traffic moves along spokes connected to the hub at the center.
} 
magnitudes of the impact on economic welfare or trade rather than by absolute terms.

\section{Previous Findings}

A number of CGE-based East Asian FTA studies have been published in recent years. The majority of literature has exclusively focused on the formation of an ASEAN+3 FTA, among which influential examples include Urata and Kiyota (2003) and Zhang et al. (2006)16. Urata and Kiyota (2003) reported ASEAN+3 FTA is expected to benefit all member states for which GTAP simulation results ranged from the highest of $12.5 \%$ (Thailand) to the lowest of $0.64 \%$ (People's Republic of China, PRC), while non-members, such as the EU $(-0.02 \%)$ and the US (-0.09\%), suffered losses. Zhang et al. (2006) supported such findings with their independent GTAP analysis with which an increase in the overall GDP of all East Asian countries by $1.2 \%$ has been forecasted.

On the other hand, there has also been literature that compared ASEAN+3 FTA with existing alternative FTA scenarios in East Asia, such as ASEAN+1 FTAs and the Northeast Asian trade bloc (PRC-Japan-Korea FTA). Gilbert et al. (2004) argued that a broader FTA in East Asia will bring more benefits to the region with the example of ASEAN+3 FTA vs. PRC-Japan-ROK FTA. Cheong (2005) further elaborated these findings by emphasizing the larger gains from a regional arrangement in comparison with the current format of a series of bilateral agreements for all members, especially ASEAN and Japan.

Likewise there have been a number of papers written to prove that the expected gains from regional trade liberalization is far greater than the cost, of which magnitude varies among the member states depending on their current economic structure. Yet, again, a thorough quantitative analysis that encompasses various formats of regional arrangements to actually compare the gains from different structures has been neglected. In this regard, a study on three most often cited formulations (ASEAN+3, ASEAN+6 and APEC) to quantify each of the expected gains and design possible policy recommendations might be very timely.

\section{ASEAN+3 FTA vs. ASEAN+6 FTA vs. APEC FTA}

For the purpose of this paper, a trade-linked multi-sector and multi-country CGE models for each scenario of ASEAN+3, ASEAN+6 and APEC FTA were developed to measure the impact of each regional economic integration arrangement on the economic performance (GDP), trade volume and trade intensity of each participating economy. Due to the CGE model's inability to incorporate non-quantifiable variables, such as rules of origin

16 Kawai (2007) 
and non-tariff measures, all the results were translated to measurable indices.

First on the list were the economic welfare outcomes measured in terms of the effects of regional arrangement on each economy's GDP as illustrated in [Table 1]. A simple interpretation would be that APEC-wide integration yields the most among the three given options, for which the additional gain for China (177\%) and Japan (92\%) far exceeds that for Korea (17\%) or ASEAN (15\%). By viewing the numbers plainly, both China and Japan are expected to be more motivated to pursue wider-regional integration and if true, this could be one of the reasons for the stagnated East Asia-exclusive regional integration process.

Table 1.

CGE Simulated Effects of FTA on each member economies' GDP with GTAP7 (GTAP6) ${ }^{17}$

\begin{tabular}{c|c|c|c|c|c}
\hline & ASEAN+3 & ASEAN+6 & APEC & \multicolumn{2}{|c}{ Additional Benefits**** } \\
\cline { 5 - 6 } & & & $+3 \rightarrow+6$ & $+6 \rightarrow$ APEC \\
\hline \hline Korea & $0.56(1.85)$ & $0.60(1.87)$ & $0.71(2.15)$ & $9 \%(1 \%)$ & $17 \%(15 \%)$ \\
\hline China & $0.12(0.04)$ & $0.13(0.06)$ & $0.35(0.57)$ & $6 \%(61 \%)$ & $177 \%(851 \%)$ \\
\hline Japan & $0.04(0.01)$ & $0.06(0.04)$ & $0.12(0.12)$ & $45 \%(510 \%)$ & $92 \%(159 \%)$ \\
\hline ASEAN & $0.56(0.19)$ & $0.57(0.23)$ & $0.66(0.31)$ & $3 \%(21 \%)$ & $15 \%(37 \%)$ \\
\hline AusNZ* & $-0.03(-0.03)$ & $0.16(0.12)$ & $0.17(0.13)$ & $677 \%(483 \%)$ & $4 \%(5 \%)$ \\
\hline India & $-0.03(-0.03)$ & $0.52(0.26)$ & $0.57(0.39)$ & $2015 \%(853 \%)$ & $9 \%(52 \%)$ \\
\hline USA & $-0.005(-0.0004)$ & $-0.007(-0.0012)$ & $0.020(-0.001)$ & $-33 \%(-200 \%)$ & $406 \%(8 \%)$ \\
\hline O_APEC** & $-0.04(-0.01)$ & $-0.05(-0.01)$ & $0.15(0.016)$ & $-25 \%(-31 \%)$ & $430 \%(211 \%)$ \\
\hline EU & $-0.018(-0.008)$ & $-0.024(-0.012)$ & $-0.048(-0.018)$ & $-39 \%(-55 \%)$ & $-95 \%(-54 \%)$ \\
\hline ROW*** & $-0.025(-0.021)$ & $-0.036(-0.031)$ & $-0.066(-0.053)$ & $-46 \%(-47 \%)$ & $-83 \%(-70 \%)$ \\
\hline
\end{tabular}

Source : Author's CGE Calculation using GTAP7 (GTAP6)

* AusNZ = Australia and New Zealand; *** ROW = Rest of the World;

** O_APEC = Other APEC countries (Canada, Chile, Mexico, Papua New Guinea, Peru and Russia);

**** Changes in calculated gain/loss from each trade liberalization scenario measured in percentage ratio;

17 Result of author's CGE analysis for which methodology, including the versions of GTAP used, is elaborated in detail in Appendix I. The CGE analysis result of GTAP 6 has been adopted from Lee (2009). 


\section{Version 6 vs. Version 7}

[Table 1] illustrates the clear differences between GTAP version 6 and 7 in estimating the expected magnitudes of impact on the target economy from each tested scenario. While the expected impacts on the Korean GDP have been significantly decreased, the impacts on the ASEAN and the US have been increased for all three scenarios using the updated version. The GTAP 7 has also estimated larger impacts on all tested regions for ASEAN+3 and ASEAN+6 cases whereas that of the APEC FTA remained at the same level. Although the decreased economic impacts of tested free trade arrangements on subject economies, in this particular case mainly Korea, can be easily explained by the nature of CGE model analysis to provide estimates on the economic impacts from tariff reduction that gets lowered every year in accordance with various international agreements, the increased estimates requires a better explanation.

Table 2.

Quick Comparison between GTAP 6 and GTAP 718

\begin{tabular}{c|c|c}
\hline Item & GTAP 6 & GTAP 7 \\
\hline \hline Reference Year & 2001 & 2004 \\
\hline Number of Sectors & 57 & 113 \\
\hline Number of Regions & 87 & 2004, using World Bank Data \\
\hline Macroeconomic Data & 2001, using World Bank Data & 2004, using World Bank Data \\
\hline Government Consumption & 2001, using World Bank Data & $\begin{array}{c}\text { 2004, COMTRADE through } \\
\text { ERS, USDA }\end{array}$ \\
\hline Trade Data & $\begin{array}{c}\text { 2001, COMTRADE through } \\
\text { ERS, USDA }\end{array}$ & $\begin{array}{c}\text { 2004, New OECD dataset and } \\
\text { different methodology }\end{array}$ \\
\hline Domestic Support & 2001, OECD PSE DATA & 2004, or the latest available \\
\hline Export Subsidies & 2001, Francois and & 2004, Francois and Wöz \\
\hline MFA Export Tax & 2001, MacMAP & 2004, MacMAP \\
\hline Agricultural Tariffs & 2001, MacMAP and AMAD & 2004, MacMAP \\
\hline Merchandise Tariffs & Revised & $\begin{array}{c}\text { 2000 energy prices data updated } \\
\text { to 2004 using price indices }\end{array}$ \\
\hline Energy Data & to97 energy prices data updated & $\begin{array}{c}\text { Updated using 2004 GTAP } \\
\text { Data }\end{array}$ \\
\hline Demand Elasticities & for using price indices \\
\hline Population Data & 2001 Data from World Bank & 2004, using World Bank Data \\
\hline Time Series Trade & $\begin{array}{c}\text { Extended to 2002 using new data } \\
\text { Extended to 2006 using new } \\
\text { data for 1992-2006 }\end{array}$ \\
\hline
\end{tabular}

18 Badri (2009): GTAP Version 7 Information Booklet 
For this purpose, the major differences made in the new version of GTAP have been outlined in [Table 2] and found to be the reference year: 2004 from 2001. What has signified such an update of all the key data sets to the 2004 reference year in GTAP 7 is China's accession to the WTO as a means to implement its announced Open Door policy in 2001. Since this incident, China has been rapidly and increasingly engaged in the world economy accounting for $37.1 \%$ of total world trade in 2004, a fivefold increase from $7.5 \%$ recorded in 2001.19 On its path to being successfully incorporated into world trade system, China did not take long to be listed among the Top 3 trade partners, and hence boosted intra-regional trade, for all major economies in the APEC region. With this remarkable change in global economy, the estimated economic impacts of ASEAN+3 and ASEAN+6 on the subject economies' GDPs increased by threefold for all Asian countries (China, Japan and ASEAN) except for Korea. ${ }^{20}$ Meanwhile, the estimated negative economic impacts on excluded economies for each tested scenario also increased to some extent.

\section{The US as an Exception}

Another noticeable point lies in the estimates for the US; the expected economic impacts of tested scenarios on the US' GDP increased by more than 10 times using GTAP 7, and what is more is that the GDP changes were abnormal with GTAP 6. While the dramatic increase can, again, be explained with the introduction of China in the global market, to whom the US has accrued the largest trade deficit,21 the results from version 6 call for further elaboration. This is because the impact of the APEC FTA, illustrated in [Table 1], is still very low for the US (0.020) despite the 406\% improvement from the ASEAN+6 FTA of version 7, while the magnitude of negative impacts of exclusion from Asian integration (-0.005 and -0.007 for ASEAN+3 and ASEAN+6 respectively) is lower than any other part of the world (unlike the general expectation). If the simulated results were to be adopted plainly on the surface, the best scenario for the US would seem to be to disconnect itself from the East Asian regionalization process but ensure its size remains small in the ASEAN+3 FTA format.

The concluding remarks for the US, obviously, change when the unique trade structure of the US is considered; there are two characteristics of the US trade pattern which could

19 Source: PRC National Bureau of Statistics and PRC General Administration of Customs, China's Customs Statistics (http://www.uschina.org/statistics/tradetable.html)

20 The case of Korea can be explained with the role of trade balance in determining the economic gains from bilateral trade liberalization arrangements; Korea has accrued a significant amount of trade surplus against China, and hence, the economic gain from mere tariff reduction with China is negligible. This concept will be further elaborated in later section on the impacts of KORUS and Korea-EU FTAs.

21 The trade imbalance between China and the US has become one of many obstacles to APEC regional economic integration together with Sino-Japanese rivalry. 
have easily affected the simulation outcome and made it sound deceiving. Firstly, the contribution of trade to its total GDP has been maintained at a rate of less than $10 \%$ even after China's accession to the WTO, which is exceptionally low for the globalization era of 21st century. For this reason, the impact of a launch of an East Asian trading bloc is relatively smaller on the US than on any other regions including the 'Rest of the World,' despite more than a 10 times increase in version 7 with China effects and its traditional close political and economic relationship with East Asian countries since the end of the Second World War. [Table 3] shows in detail that the contribution of trade with the ASEAN+3 countries, whose major players are all listed among the top 10 trade partners of the US, to its GDP is approximately 3\%.

Table 3.

US Top 10 Trade Partners (in billions of USD)22

\begin{tabular}{|c|c|c|c|c|}
\hline \multicolumn{2}{|c|}{ Measure } & 2000 & 2008 & $2000 \sim 2008$ \\
\hline \multirow{8}{*}{$\begin{array}{c}\text { Annual } \\
\text { Trade } \\
\text { Breakdown } \\
\text { for US }\end{array}$} & GDP* & 9,817 & 14,264 & 88,189 \\
\hline & Export (\% to GDP) & $780(8 \%)$ & $1,300(9 \%)$ & $8,149(9 \%)$ \\
\hline & Goods* & 558 & 897 & 5,676 \\
\hline & Services* & 222 & 403 & 2,474 \\
\hline & Import (\% to GDP) & $1,217(12 \%)$ & $2,100(15 \%)$ & 13,831(16\%) \\
\hline & Goods* & 1,025 & 1,757 & 11,582 \\
\hline & Services* & 192 & 343 & 2,249 \\
\hline & Trade Balance & -436 & -800 & $-5,682$ \\
\hline PRC & Trade Balance & $-\quad 84$ & $-\quad 266$ & - 1,513 \\
\hline Japan & Trade Balance & $\begin{array}{l}-81 \\
-\quad 81\end{array}$ & 73 & -706 \\
\hline Canada & Trade Balance & $-\quad 53$ & 75 & -568 \\
\hline Mexico & Trade Balance & $-\quad 24$ & 64 & $-\quad 430$ \\
\hline Germany & Trade Balance & $-\quad 29$ & 43 & -365 \\
\hline Malaysia & Trade Balance & $-\quad 15$ & 18 & $-\quad 59$ \\
\hline Ireland & Trade Balance & 9 & 23 & -157 \\
\hline Italy & Trade Balance & $-\quad 14$ & 21 & - 156 \\
\hline Korea & Trade Balance & $-\quad 12$ & 13 & -127 \\
\hline Taiwan & Trade Balance & -16 & 11 & $-\quad 123$ \\
\hline & rade Balance & $\begin{array}{ll}-\quad 337 \\
\end{array}$ & $\begin{array}{l}-607 \\
\end{array}$ & - 4,303 \\
\hline$\%$ to To & Trade (\% to GDP) & $77 \%(3)$ & $76 \%(4)$ & $76 \%(5)$ \\
\hline Contributi & n ASEAN+3 (to GDP) & $44 \%(2)$ & $46 \%$ (3) & $44 \%$ (3) \\
\hline
\end{tabular}

Note : ASEAN+3(blue) and APEC (grey) members comprised seven of Top 10 trade partners

22 Source : KITA (Except for $\left(^{*}\right)$ from US Department of Commerce as of May 2009) 
Furthermore, and possibly more critical with respect to the calculated harmful effect on the GDP of the US under the APEC FTA, this trade deficit runner of the century has also been the world's service provider comprising approximately 30\% of its total exports. Unfortunately, however, the service sector has yet been clearly defined globally that the industry's effective protectionism exhibits more of the non-tariff barriers than quantifiable ones. Also because information on the service industry is particularly rare for East Asia, the gains for the US from its trade liberalization with East Asia, both bilaterally with any member country or multilaterally with the region as a whole, is practically difficult to obtain. ${ }^{23}$

Thus, it will be fairer to state that the numbers representing the US' gains from the East Asian trade liberalization are the minimum coefficients having only considered the trade of goods. Despite this analytical limitation, however, the service sector cannot be neglected as it is an important ingredient of trade liberalization in East Asia. This is reflected by service and investment having constituted an independent crucial pillar of all the major regional trade related negotiations since the year 2000. This trend was clear when service and investment had served as one of the key issues for the KORUS and Japan-ASEAN FTA negotiations. In other words, the US is guaranteed to realize larger gains than expected while other countries with heavier concentration towards the trade of goods are to observe lessened gain due to actual significance of the service sector.

The results from the developed CGE model, however, are still worth further analysis for the two following reasons: one, the obtained results confirm two important macroeconomic theories, economies of scale (the level of the gain is directly related to the scope of economy) and the discriminative aspect of any regional trade arrangement by definition (trade diversion), to be elaborated further below. And two, regardless of their accuracy, the retrieved numbers illustrate a trend of trade diversion, an expected mal effect from the establishment of any trade bloc, which all scenarios obeyed, consequently, confirming their validity as coefficients.

\section{Estimates of Economic Effects}

In accordance with the economies of scale, the CGE results in [Table 1] displayed that each member economy is to receive a stronger impact on its GDP when the size of its trade bloc is larger. As evidenced by the deepened GDP cut on the non-ASEAN+6 members when the model is expanded to three additional countries, an economy is to experience severer impact if a trade bloc that it is not a member expands. In short, every country is to expect more improvement in their GDP when the membership of its participating trade bloc

\footnotetext{
${ }^{23}$ As the most of the barriers exerted on Service sector in East Asia are the non-trade barriers, which has yet been incorporated in the CGE model, the tool recognized it as "unquantifiable" due to Code Unavailability and treated as "0".
} 
expands.

Additionally, the critical component that determines the extent to which an economy's GDP is affected by the questioned trade liberalization naturally is that economy's dependence on the trade covered by the arrangement. Accordingly, and as expected, Korea, of which more than $70 \%$ of GDP comes from global trade, came at the top of the beneficiary list for all scenarios. Even more precisely, the additional benefits expected by the membership expansion from ASEAN+3 to ASEAN+6 and, again, to APEC amounted to 9\% and $17 \%$ (1\% and $15 \%$ in version 6$)$, respectively, for Korea in reflection of its major trade partners being China, Japan and the US. The same pattern was also true for China (6\% and 177\%) and ASEAN (3\% and 15\%), while Japan forecasted meaningful additional benefits from the first membership expansion into ASEAN+6 (45\%) having closer economic ties with the three additional members of ASEAN+6 than any other East Asian countries.

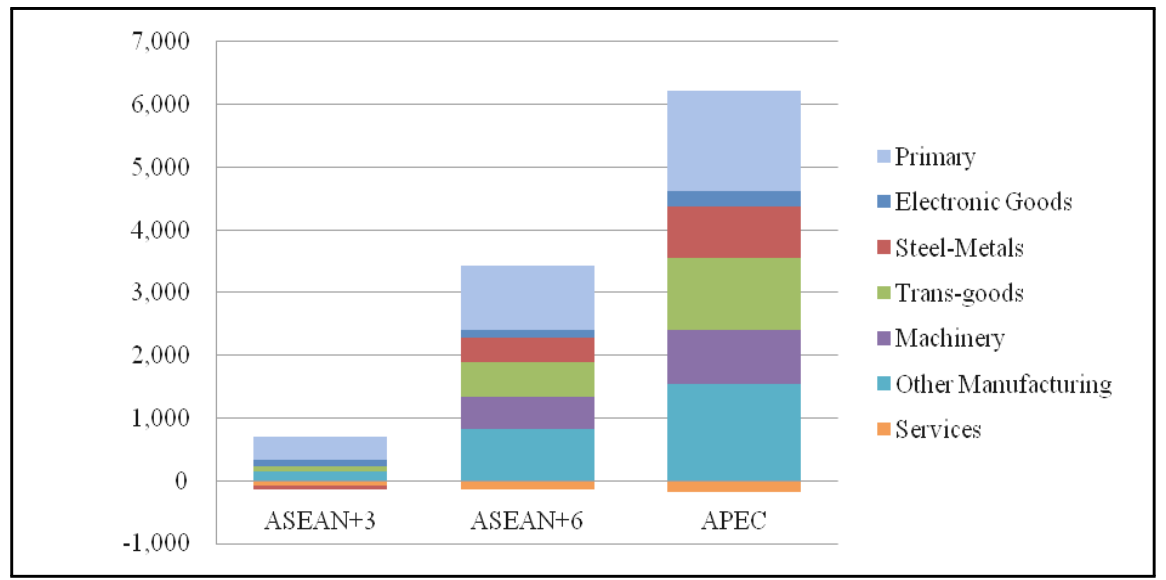

Source : Author's CGE Calculation using GTAP 7

Figure 1. Additional trade volume growth by sector under different arrangements

To confirm the above findings, the additional total trade volume expected under each scenario has been graphically illustrated in [Figure 1], in which the two-step expansion displayed 580\% and 183\% increase respectively. Among the seven specified sectors, the simulation results showed the maximum increase in the Primary, mainly agricultural, industries under every set scenario. This reflects the current high protectionism imposed in the form of high tariffs or quotas on agricultural goods traded in East Asia, of which almost all countries' sensitive items cover the majority of agricultural products. On the other hand, considering the sensitivity of these items in each involved country, such a dramatic boost of the primary goods traded might not be a realistic forecast. A more practical understanding would be to view the potential gains from free trade as these numbers suggest. 
Having said that, the gains displayed in [Table 1], should not be taken blindly but considered in connection with the analyzed results on countries by sector. This is because the combined analysis, as illustrated in [Figure 2], implies that substantial gains for Asian countries are expected from the primary sector in which the average tariff is still high. In this regard, the full gains are very unlikely to be realized even under high quality WTO+ trade agreements, as even in KORUS FTA, which has been recognized as one of the highest liberalization degrees (94\%). The national sensitive items - rice for Korea and shipbuilding for the US - were exempted from trade liberalization packages.

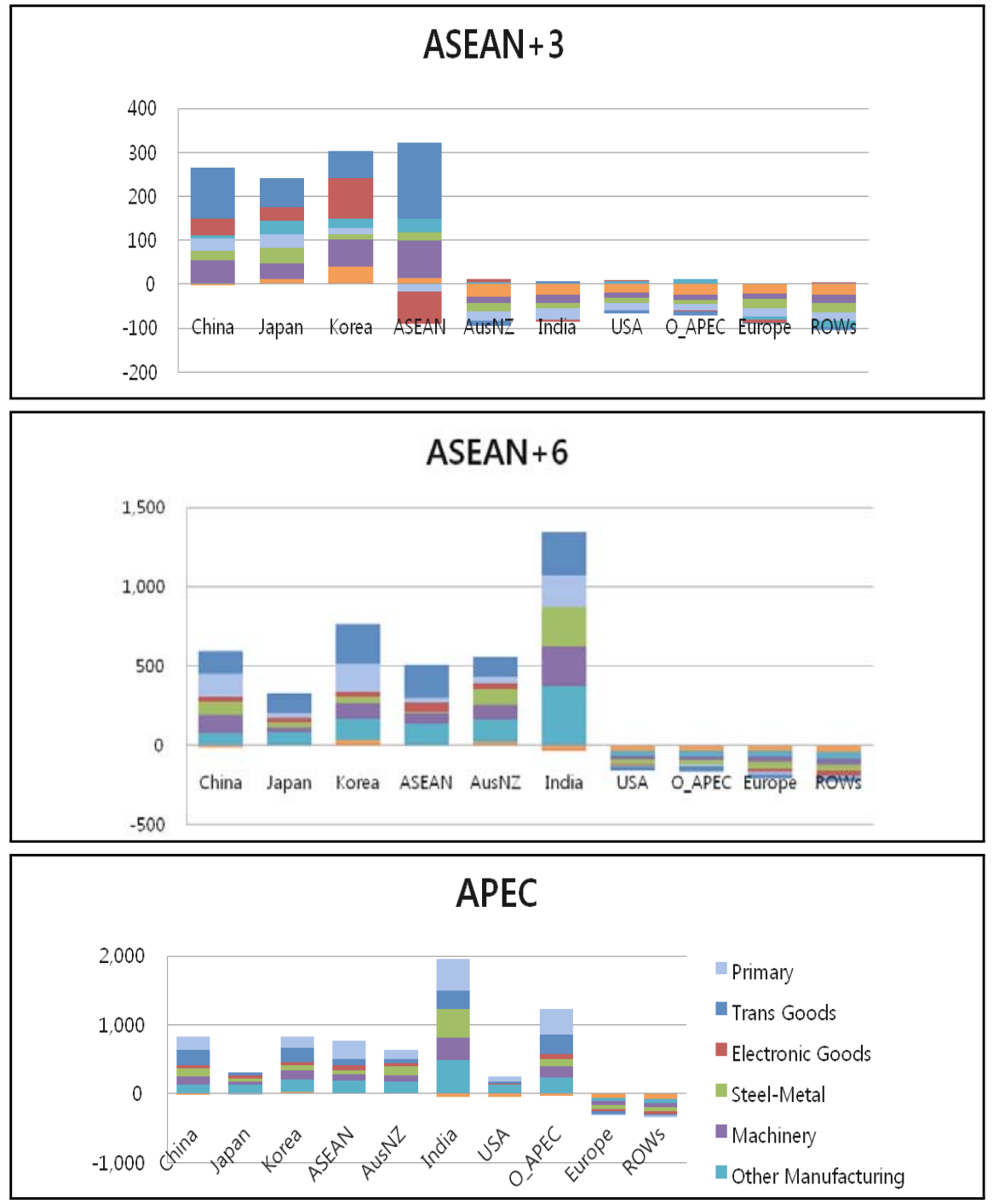

Source : Author's CGE Calculation using GTAP 7

Figure 2. Changes in Trade Volume by each Sector under Different Scenarios 


\section{Trade Diversion is Expected}

A formation of any trade bloc, however, is not a perfect solution to break through economic difficulties, especially in times of global crisis like today. The damage experienced by non-members from the established trade bloc increases as the size of the bloc expands, in the same manner as the gains for the participating economies are directly proportional to the size of the membership. This is the mal effect expected from both the multilateral and bilateral trade agreements since they are discriminatory and, consequently, result in posing negative trade diversion effects on the excluded countries. ${ }^{24}$

On the other hand, for this very reason, all trade blocs have their own threshold in membership; once the size reaches the tipping point at which the cost of exclusion exceeds that of joining, countries rush into the arrangement with the fear of being left out from the benefits of liberalized trade networks. In other words, because the damage caused by a trade arrangement increases with the size, there comes a point at which scope of trade diversion towards the members becomes visible enough to force a non-member government to make the necessary payments (administration and negotiation cost) and be saved from more severe trade injuries on its economy in the future. [Table 1] displays this so-called domino effect with the magnitude of negative impacts on non-member economies' GDPs under the APEC FTA, which exceeds the corresponding figures for ASEAN+6 configurations. The scale of such trade diversion caused by discriminative trade arrangements on each non-member become clearer in [Figure 2], in which the changes of the trade volume for the affected countries have been identified by sector.

\section{KORUS and Korea-EU FTAs: With or Without?}

Having comparatively analyzed the effects of different sizes of possible East Asian regionalization, this paper, hereon, sets to verify the impacts of hub-and-spoke-ism in East Asia. The two most foreseeable issues that could arise from the current structure of the three ASEAN+1 FTAs are, first, economically inferior output for a region as a whole by encouraging trade diversion towards the hub economy. Wonnacott (1996) has pointed out that investment will typically tend to converge towards the most efficient industries in the hub country and that spillover effects will be limited. Besides, both the trade-related costs and business inefficiency will be systematically maximized in a hub-and-spoke structure as the hub will have to construct a complex trade network with multiple spokes, in which firms from the hub country will enjoy advantages in attaining monopolistic positions by hindering competitors from expanding from one spoke to another. Such a Spaghetti Bowl Effect, created or amplified by this complex trade network in turn, may further produce a profusion

24 Yue (2007) 
of FTAs that can make the whole region less attractive to foreign direct investments (FDI).

Secondly, a hub-and-spoke type can easily result in definite division across political philosophies rather than the intended cooperation. ${ }^{25}$ Findlay, in 2000, concluded that the biggest danger of this hub-and-spoke-ism is the strong incentive for economies to race for the 'hub' position. In realistic terms, as the share of the benefits from integration is bound to be biased towards the hub economy, as briefly mentioned before, ${ }^{26}$ while the spoke economies are to be marginalized both economically and politically; the evolution of political tension against the hub economy is inevitable. Such aspirations will escalate even higher if the hub country can gain greater bargaining power in new FTA negotiations with both intra- and extra-regional partners. For these various reasons, every involved country will, once the process begins, challenge to become the regional FTA hub country, and, hence, the region will be covered with layers of discriminatory structures and underlying conflicts. Consequently, no sincere cooperation among neighboring nations to jointly tackle the regional issues, including non-traditional security threats and environment protection schemes, will be possible.

Both mal effects are, unfortunately, currently observed in East Asia. East Asia is already suffering from regional divisiveness, which began with the rivalry between China and Japan for regional leadership but intensified due to fierce competition for the hub position among virtually all involved nations, instead of cooperation despite recent rapid proliferation regionalism. From the look of current progress, the worst, yet quite probable, scenario is that East Asia will follow the footsteps of NAFTA with the establishment of a two-hub system of any combination. ${ }^{27}$ Only yet, the formulation will differ significantly from NAFTA, whose de facto hub-state is solely the US, due to uncoordinated political economy forces, and only result in the deepened intra-regional rivalries. Hence, should ASEAN fail to fulfill its duties as a hub economy, which it has formally obtained through three individual ASEAN+1 FTAs with Northeast Asian countries, any one of the many Northeast Asian countries can easily become a de facto hub by effectuating another bilateral FTA with other countries. ${ }^{28}$ For example, Korea could become a bridge between East Asia and North American with an effectuated KORUS FTA while ASEAN remains the hub of East Asian economic cooperation under this setting. And, such a bipolar system, of any combination, would not only dilute the benefits of economic regionalization externally but also deepen internal conflicts and prevent East Asia from truly harmonizing and realizing long-term mutual gains.

\footnotetext{
25 Baldwin (2007)

26 As an all-roads-lead-to-Rome transportation system favors industrial location in Rome, a hub-and-spoke arrangement favors industry in the hub nation at the expense of industry in the spoke nations.

27 Although Mexico has established free trade with 32 countries through 10 additional FTAs, it is the US that is considered as the hub for NAFTA for its dominating political and economic power in the region.

28 Inkyo Cheong (2005)
} 
Furthermore, as the exclusive political and economic leadership that the hub country will win in East Asia exceeds that of any other region, a singular hub-and-spoke regionalism is not enviable even if it were possible. This is because the region simply lacks a middle-point that could best represent the vast scope of East Asia both in terms of territory and development stages involved. Thus, the EU-type of multilateral economic integration, in which major economies drive and smaller economies support in an equal stance, will also be the most desirable format for East Asia.

Having said that, this paper has selected Korea as an imaginary hub country with the KORUS FTA and Korea-EU FTA on pre-established ASEAN+3 and ASEAN+6 (termed 'plain' in this section) for further quantitative analysis.

The scenarios that were tested are as follows:

(1) ASEAN+3_KORUS: ASEAN+3 FTA with KORUS FTA

(2) ASEAN+3_EU: ASEAN+3 FTA with Korea-EU FTA

(3) US\&EU+3: ASEAN+3 with both KORUS and Korea-EU FTA

(4) ASEAN+6_KORUS: ASEAN+6 with KORUS FTA

(5) ASEAN+6_EU: ASEAN+6 with Korea-EU FTA

(6) US\&EU+6: ASEAN+6 with both KORUS and Korea-EU FTA

By building this model, the discussed downsides of hub-and-spoke type regional economic integration were verified with which previous findings for the APEC FTA, the largest trading bloc among the given possibilities, were compared. In looking at the results, as illustrated in [Table 4], three interesting correlations were found as well as the confirmation of expectations in accordance with previous findings. So as to begin with what was expected from the aforementioned neglected service sector in this paper is the expected negative economic impacts on the US despite the KORUS FTA under both the ASEAN+3 and ASEAN+6 FTAs. Although the upgraded version gave more realistic results of 50\% improvement from the plain ASEAN+3 FTA (-325\% in version 6) and 38\% from plain ASEAN+6 FTA (-92\% in version 6) to those with the KORUS FTA, it was found that the US would experience economic losses if the free trade arrangements only dealt with tariff reductions.

Secondly, as anticipated from the understandings on the aforementioned hub-and-spoke effects, the results show concentrated benefits on the hub state, Korea, in sequence with decreased gains from East Asian regionalization with either the KORUS, Korea-EU FTA or both, for ASEAN and Japan. This phenomenon obviously reflects the trade diversion and concentration consequences taking place in the pre-established East Asian trade bloc, regardless of its size. Yet, the impact clearly gets diluted across the membership and the levels of both gains and losses for the hub state and spoke members are moderately decreased under the larger membership of ASEAN+6. 
Table 4.

CGE Analysis on Effects of KORUS and Korea-EU FTAs

\begin{tabular}{|c|c|c|c|c|c|c|c|c|c|c|c|c|c|c|c|}
\hline & \multicolumn{4}{|c|}{ ASEAN+3 } & \multicolumn{4}{|c|}{ ASEAN+6 } & \multirow{2}{*}{$\begin{array}{c}\text { APEC } \\
\text { Only }\end{array}$} & \multirow{2}{*}{$\begin{array}{l}\text { US\& } \\
\text { EU+3 }\end{array}$} & \multirow{2}{*}{$\begin{array}{l}\text { Plain+3 } \\
\rightarrow \text { US\&EU }\end{array}$} & \multirow{2}{*}{$\begin{array}{c}\text { US\& } \\
\text { EU+6 }\end{array}$} & \multirow{2}{*}{$\begin{array}{c}\text { Plain+6 } \\
\rightarrow \text { LS\&EL }\end{array}$} & \multirow{2}{*}{$\begin{array}{l}\text { Us\&Ed+3 } \\
- \text { iseECt+6" }\end{array}$} & \multirow{2}{*}{$\begin{array}{l}\text { US\&EC+C } \\
\rightarrow \mathrm{APEC}\end{array}$} \\
\hline & KORLIS & $\mathrm{EU}$ & Plain $\rightarrow$ US & Plain $\rightarrow \mathrm{EU}$ & KORUS & $\mathrm{EU}$ & Plain $\rightarrow$ US & Plain $\rightarrow E \mathrm{E}$ & & & & & & & \\
\hline Korea & \begin{tabular}{|c|}
0.70 \\
$(2.20)$
\end{tabular} & $\begin{array}{c}0.69 \\
(2.04)\end{array}$ & $\begin{array}{c}26 \% \\
(19 \%)\end{array}$ & $\begin{array}{c}25 \% \\
(10 \%)\end{array}$ & $\begin{array}{c}0.75 \\
(2.21)\end{array}$ & $\begin{array}{c}0.74 \\
(2.06)\end{array}$ & $\begin{array}{c}24 \% \\
(18 \%)\end{array}$ & $\begin{array}{c}23 \% \\
(10 \%)\end{array}$ & $\begin{array}{c}0.701 \\
(2.153)\end{array}$ & \begin{tabular}{|c|}
0.836 \\
$(2.386)$
\end{tabular} & $\begin{array}{c}50 \% \\
(29 \%)\end{array}$ & $\begin{array}{c}0.884 \\
(2.401)\end{array}$ & $\begin{array}{c}46 \% \\
(28 \%)\end{array}$ & $\begin{array}{c}6 \% \\
(1 \%)\end{array}$ & $\begin{array}{l}-20 \% \\
(-10 \%)\end{array}$ \\
\hline China & \begin{tabular}{|c|}
0.12 \\
$(0.05)$
\end{tabular} & $\begin{array}{c}0.12 \\
(0.03)\end{array}$ & $\begin{array}{c}0 \% \\
(34 \%)\end{array}$ & $\begin{array}{c}-2 \% \\
(-10 \%)\end{array}$ & $\begin{array}{c}0.13 \\
(0.073)\end{array}$ & $\begin{array}{c}0.12 \\
(0.057)\end{array}$ & $\begin{array}{c}0 \% \\
(21 \%)\end{array}$ & $\begin{array}{c}2 \% \\
(-6 \%)\end{array}$ & $\begin{array}{c}0.350 \\
(0.575)\end{array}$ & $\begin{array}{l}0.117 \\
(0.047)\end{array}$ & $\begin{array}{c}-2 \% \\
(25 \%)\end{array}$ & $\begin{array}{c}0.124 \\
(0.070)\end{array}$ & $\begin{array}{c}-2 \% \\
(16 \%)\end{array}$ & $\begin{array}{c}6 \% \\
(49 \%)\end{array}$ & $\begin{array}{c}183 \% \\
(723 \%)\end{array}$ \\
\hline Japan & $\begin{array}{c}0.042 \\
(0.006)\end{array}$ & $\begin{array}{l}0.042 \\
(0.007)\end{array}$ & $\begin{array}{c}-3 \% \\
(-25 \%)\end{array}$ & $\begin{array}{c}-2 \% \\
(-8 \%)\end{array}$ & $\begin{array}{c}0.062 \\
(0.043)\end{array}$ & $\begin{array}{c}0.06 \\
(0.043)\end{array}$ & $\begin{array}{l}-2 \% \\
(-3 \%)\end{array}$ & $\begin{array}{c}-2 \% \\
(-1 \%)\end{array}$ & $\begin{array}{c}0.121 \\
(0.115)\end{array}$ & $\begin{array}{c}0.041 \\
(0.005)\end{array}$ & $\begin{array}{c}-5 \% \\
(-32 \%)\end{array}$ & $\begin{array}{c}0.061 \\
(0.043)\end{array}$ & $\begin{array}{c}-4 \% \\
(-4 \%)\end{array}$ & $\begin{array}{c}47 \% \\
(754 \%)\end{array}$ & $\begin{array}{c}99 \% \\
(170 \%)\end{array}$ \\
\hline ASEAN & \begin{tabular}{|c|}
0.55 \\
$(0.19)$
\end{tabular} & $\begin{array}{c}0.55 \\
(0.18)\end{array}$ & $\begin{array}{l}-0.1 \% \\
(-1 \%)\end{array}$ & $\begin{array}{c}-1 \% \\
(-1 \%)\end{array}$ & $\begin{array}{c}0.57 \\
(0.22)\end{array}$ & $\begin{array}{c}0.57 \\
(0.22)\end{array}$ & $\begin{array}{c}0 \% \\
(-1 \%)\end{array}$ & $\begin{array}{l}-1 \% \\
(-1 \%)\end{array}$ & $\begin{array}{c}0.659 \\
(0.311)\end{array}$ & \begin{tabular}{|c|}
0.548 \\
$(0.183)$
\end{tabular} & $\begin{array}{l}-1 \% \\
(-2 \%)\end{array}$ & $\begin{array}{c}0.566 \\
(0.222)\end{array}$ & $\begin{array}{c}-1 \% \\
(-2 \%)\end{array}$ & $\begin{array}{c}3 \% \\
(21 \%)\end{array}$ & $\begin{array}{l}16 \% \\
(40 \%)\end{array}$ \\
\hline USA & $\begin{array}{c}-0.005 \\
(-0.002)\end{array}$ & $\begin{array}{c}-0.005 \\
(-0.0006)\end{array}$ & $\begin{array}{c}50 \% \\
(-325 \%)\end{array}$ & $\begin{array}{c}-4 \% \\
(-50 \%)\end{array}$ & $\begin{array}{c}-0.004 \\
(-0.002)\end{array}$ & $\begin{array}{c}0.57 \\
(0.22)\end{array}$ & $\begin{array}{c}38 \% \\
(-92 \%)\end{array}$ & $\begin{array}{c}-5 \% \\
(-8 \%)\end{array}$ & $\begin{array}{c}0.0196 \\
(-0.0011)\end{array}$ & \begin{tabular}{|c|}
-0.0027 \\
$(-0.0017)$
\end{tabular} & $\begin{array}{c}44 \% \\
(-325 \%)\end{array}$ & $\begin{array}{c}-0.0043 \\
(-0.0024)\end{array}$ & $\begin{array}{c}33 \% \\
(-100 \%)\end{array}$ & $\begin{array}{c}-59 \% \\
(-41 \%)\end{array}$ & $\begin{array}{l}556 \% \\
(54 \%)\end{array}$ \\
\hline EU & $\begin{array}{c}-0.018 \\
(-0.008)\end{array}$ & $\begin{array}{c}-0.019 \\
(-0.0053)\end{array}$ & $\begin{array}{c}-5 \% \\
(-9 \%)\end{array}$ & $\begin{array}{c}23 \% \\
(31 \%)\end{array}$ & $\begin{array}{c}-0.026 \\
(-0.012)\end{array}$ & $\begin{array}{c}-0.020 \\
(-0.0094)\end{array}$ & $\begin{array}{c}-7 \% \\
(-3 \%)\end{array}$ & $\begin{array}{c}10 \% \\
(21 \%)\end{array}$ & $\begin{array}{l}-0.0475 \\
(-0.0183)\end{array}$ & \begin{tabular}{|c|}
-0.0152 \\
$(-0.0055)$
\end{tabular} & $\begin{array}{l}14 \% \\
(29 \%)\end{array}$ & $\begin{array}{c}-0.0219 \\
(-0.0095)\end{array}$ & $\begin{array}{l}10 \% \\
(20 \%)\end{array}$ & $\begin{array}{c}-44 \% \\
(-73 \%)\end{array}$ & $\begin{array}{l}-117 \% \\
(-93 \%)\end{array}$ \\
\hline
\end{tabular}

Source : Author's CGE Calculation using both GTAP 6 and 729

Furthermore, an examination of the data shows the countries who traditionally had been major trade partners of the subject country with whom the hub state had newly established a liberalized trade network or enjoyed a trade surplus with, the hub state suffer more than the others. Hence, it is Japan, who has not only been the major trade partner, but also has traditionally enjoyed a significant trade surplus towards both the hub state (Korea) and the subject country (the US), which suffers the most $(-3 \%$ or $-25 \%$ in versions 7 and 6

${ }^{29}$ Each simulated result compared with previous data on additional benefits expected from corresponding membership expansions. 
respectively) under ASEAN+3 with the KORUS FTA. On the contrary, ASEAN, to which end Korea accumulated a moderate trade surplus and with whom the US has formed as strong a trade relationship as the three Northeast Asian countries, the harm-to-be-caused is considerably small (-1\%). Therefore, the APEC FTA is the best scenario for all participating spoke states, while it is the worst for the non-participating spike state. In this particular case, becoming a spoke-state with the Korea-EU FTA to receive leveraged gains from a free trade area in Asia is definitely better than being totally excluded for the EU. On the other hand, the US, an APEC member economy, forecasts the largest gain under the APEC FTA together with China, Japan and ASEAN. Considering the consequent trade diversion towards the hub state, Korea, naturally greater gains are expected with the membership expansion to the APEC FTA under which a hub-and-spoke formation no longer exists for both ASEAN and Japan. In contrast, the best scenario for Korea, the hub state, obviously would be the ASEAN+6 (expanded membership within East Asia) with both the KORUS and Korea-EU FTAs.

On the other hand, however, there also were two interesting findings to be discussed in connection with the hub-and-spoke effects mentioned above: One is that the estimates suggest China's lack of loss from becoming a spoke-state under the KORUS FTA in both the ASEAN+3 and ASEAN+6 FTA scenarios, while those under the Korea-EU FTA give expected negative impacts in both versions, and the other is that the EU is still expected to experience losses despite the Korea-EU FTA under East Asian regionalization. The opposing outcomes for these two parties are in fact due to the same principle: the impact of changes in trade direction determines the gains or losses for the economy under any new trade arrangements. For China, in particular as demonstrated in [Table 5], the trade surplus gained from the changed trade direction between China and Korea is expected to surpass the losses accrued from diminished trade with the US. As a result, this particular hub-and-spoke layout can be beneficial to China in total because the magnitude of additional gain accompanied by membership expansion, especially to the APEC FTA, in which hub-and-spoke effects are eliminated, is lessened from the previous findings. The EU, having been the trade deficit runner with Korea, however, is to experience more concentrated trade inflow from Korea, while existing trade with other Asian countries is to be diverted away under the discriminative character of East Asia regionalization. As a result, the EU, although having at least the Korea-EU FTA is better than not having any connection at all, will still receive a negative impact from the newly established East Asian trade bloc. 
Table 5.

Korea's Trade Balance with Trade Partners by Year (million USD)30

\begin{tabular}{c|c|c|c|c}
\hline Year & Japan & China & ASEAN & EU \\
\hline \hline 1990 & $-5,936$ & $-1,683$ & 95 & 937 \\
1991 & $-8,764$ & $-2,438$ & 1,168 & -166 \\
1992 & $-7,858$ & $-1,071$ & 1,926 & -644 \\
1993 & $-8,451$ & 1,222 & 2,800 & $-1,187$ \\
1994 & $-11,867$ & 740 & 4,640 & $-3,289$ \\
1995 & $-15,557$ & 1,742 & 7,842 & $-1,890$ \\
1996 & $-15,682$ & 2,838 & 8,237 & $-5,879$ \\
1997 & $-13,136$ & 3,456 & 7,817 & $-2,119$ \\
1998 & $-4,603$ & 5,460 & 6,193 & 7,243 \\
1999 & $-8,280$ & 4,818 & 5,458 & 7,612 \\
2000 & $-11,362$ & 5,656 & 1,960 & 7,635 \\
\hline 2001 & $-10,128$ & 4,888 & 543 & 4,705 \\
2002 & $-14,713$ & 6,354 & 1,644 & 4,587 \\
2003 & $-19,037$ & 13,201 & 1,795 & $18,5,305$ \\
2004 & $-24,443$ & 20,178 & 1,641 & 13,643 \\
2005 & $-24,376$ & 23,267 & 1,368 & 16,363 \\
2006 & $-25,392$ & 20,903 & 2,323 & 103,158 \\
2007 & $-29,880$ & 18,957 & 5,639 & 7,454 \\
\hline \hline TOTAL & $-32,704$ & 14,459 & 142,947 & \\
\hline & $-292,169$ & & & \\
\hline
\end{tabular}

A two-fold CGE model analysis using both versions 6 and 7 of the GTAP has quantitatively illustrated the gains and losses expected from potential regionalization processes in East Asia. Many scholars have argued the gains will increase as the membership expands as much as the losses of the excluded countries do. The fear of greater damage will, hence drive these countries to get connected with established trading blocs, as witnessed in the case of the EU. In spite of this domino effect, a creation of a hub state by taking an

\footnotetext{
30 Trade Data obtained from KITA, Korea
} 
option of effectuating a bilateral trade agreement with one member state of the trade bloc is not the best solution for all involved parties, except the hub state. Hence, a race for the hub position would be the most logical behavior for each participant, diminishing cooperative spirit as Findlay (2000) has pointed in his article.

Despite these confirmative findings, however, the numbers provided in this section should be used as a mere indication of gain from loss since the service sector, of which importance is growing nowadays especially when analyzing the US effects, has been totally neglected. In this regard, a follow-up study to update the figures would be necessary once sufficient data on service trade in East Asia is gathered and updated in the GTAP database.

\section{Beyond the 2009 Global Credit Crunch}

The question to be answered before drawing the blueprints for the future regional integration mechanism in East Asia is their collective choice to pursue either Pacific Asia and/or the Asia Pacific region. For the 20th anniversary of APEC this year, Bergsten, the director of the Peterson Institute of International Economics, has explicitly expressed his opinion on this - all has been achieved for dual progress. ${ }^{31}$ What he meant by this is that the time has come for East Asian countries to make a choice whether to develop APEC as THE regional integration body or to terminate it having prioritized Asia-centered integration.

Although no one has officially responded to this rather extreme suggestion, it is widely acknowledged that not a single East Asian country is ready to exclude the US in their policy design either economically or politically. Under these circumstances, East Asia is realistically facing two options: 1) Asia-centered integration with hub-and-spoke bilateralism with the US, and/or 2) Asia Pacific-wide integration. Having quantitatively analyzed the downside of hub-and-spoke-ism, the author naturally suggests the East Asian countries to take the second option. In this case, a three-step process can be envisaged. First, the US and at least one major Asian country should join the Trans-Pacific Partnership (TPP), the expanded form from P4 with potential participants including Australia, Peru, Vietnam and the US. With about half of APEC, with key economies enacted and involved, The TPP would be fully consistent with the "pathfinder" approach that APEC has adopted recently. At the second stage, the TPP should be transformed into a Free Trade Agreement in the Asia-Pacific region (FTAAP, which has been referred to as the APEC FTA in this paper for purposes of analysis). As the final and ultimate goal, this formula could then act as the "pressurizing group" to push the Doha Round forward to realize global trade liberalization as set under GATT back in 1994.

\footnotetext{
31 Bergsten (2009)
} 


\section{Conclusion}

Since as early as the 1960s, there has always been a common understanding to form a regional cooperative body in East Asia. The region responded to this during the 1997 Asian Financial Crisis with the launch of ASEAN+3 Summits. Yet, being unable to become truly independent from external forces in dealing with economic, political, and even security issues, the region failed to reach a consensus on the paths to regionalization. Consequently, there are a number of distinctive, yet interlinked, formulations that have been studied, developed and progressed simultaneously in East Asia until today in 2009. Among which this paper selected three major paths, ASEAN+3, ASEAN+6 and APEC, to quantitatively examine the potential gains and losses with CGE model analysis using both versions 6 and 7 GTAP databases. Subsequently, the KORUS and Korea-EU FTA were imposed, separately and concurrently, upon the built CGE base models to verify the effects of hub-and -spoke-ism in East Asia.

The two findings from the primary CGE model comparative analysis on the ASEAN+3, ASEAN +6 and APEC FTAs, confirmed the following conclusions: 1) whatever format a trade arrangement might take, whether FTA, RTA or trade bloc, the members are to benefit while the excluded countries are to suffer, 2) the magnitude of the gain or the loss is directly proportional to the size of the membership due to the trade diversion effects, and, 3) precisely due to the trade diversion effects, any trade arrangement has its own membership threshold beyond which all qualified countries will rush to join in. During the process, the consequences of China's successful engagement into the global trade system have been verified with the dramatic changes in the numbers in GTAP 7 from version 6 of the same CGE modeling analysis. Following China's accession to the WTO and the implementation of its Open Door policy, China has changed the patterns of global trade, especially in Asia where the economic meanings of Asian regionalism have been strengthened for both the regional and non-regional economies.

There also have been two value adding findings in this study. Firstly, the extent of gain or loss caused by a trade arrangement heavily depends on the subject economy's reliance on trade with the member states. Accordingly, Korea was the biggest beneficiary while Australia, New Zealand and India came to the top on the losing side. Unlike the common belief that the US would be highly affected by a launch of any type of East Asian trade bloc, scoring less than $10 \%$ of its GDP, trade had little effect on its economy. Last but not least, the gains from trade liberalization for Korea do not fluctuate greatly with the scope of membership. It is because of the combination of the aforementioned factors: Two of Korea's major trade partners (China and Japan) are included in the sphere from the smallest version of ASEAN+3, while the last of the top 3 (the US) exerted limited impacts on the scenarios analysis due to both economic structure (trade contributing less than 10\%) and technical restrictions (service sector being neglected). 
At the second stage, the effects of the hub-and-spoke format have been quantified in relation with East Asia's unique trade patterns. The expected gains from trade liberalization among the members were shifted towards the hub state, as Findlay (2000) argued, diminishing the welfare of the others. Additionally, the impact was found to be directly proportional to the accrued trade balance of the subject spoke country with both the hub state and the hub-destination. Thus, the phenomenon was most visible in the case of Japan followed by ASEAN, while China's existing trade deficit was large enough to actually benefit from Korea being a hub state. Furthermore, it has been found that the victim of such formulation might in fact be outside the circle depending on its past economic relationship with the hub state, with changes in distribution among the members, while the total gains from the trade liberalization remains the same. In this case, both the EU and the US were to suffer from decreased GDPs in spite of increased trade volume under this new trade arrangement with Korea being the traditional trade deficit runners with Korea. In this light, if the case study had been conducted using a country with whom the hub state had either an insignificant trade partnership or been a deficit runner, the hub-destination would have enjoyed the benefits from this newly established connection to one of the largest trade bloc.

The extent of damages on the spoke countries over the hub state's extra-regional trade arrangements may be greater in East Asia due to its exceptionally high reliance on external markets. Although it is not proved empirically here, being out of the scope of this paper, the significant gap between the amount of gains/losses expected from both the KORUS and Korea-EU FTAs supports this theory; in the same manner as the expected damages were greater under the KORUS FTA than Korea-EU FTA for all East Asian countries, whose top export destination is the US. In this light, a further study to prove this uniqueness of East Asia while re-examining the economic impacts of the ASEAN+3, ASEAN+6 and especially the APEC FTAs with service sector data incorporated, to insert the US effects properly, will be a valuable addition to this study.

\section{References}

Baker, James. 1995. The Politics of Diplomacy: Revolution, War and Peace: 1989-1992. New York. NY: Putnams.

Badri, Narayanan G. and Betina, V. Dimaranan. 2009. What's New in GTAP 7?. Information Booklet: Chapter 3 from GTAP 7.

Baldwin, Richard E. 2007. The Spoke Trap: Hub-and-Spoke Bilateralism in East Asia from China, Asia and the New World Economy with Barry Eichengreen. Yong-chol Park and Charles Wyplosz. Graduate Institute of International Studies. Geneva. February.

Bergsten, C.

1997. Open Regionalism. Institute for International Economics. Working Paper: 97-03. 
2009. Pacific Asia and the Asia Pacific: The Choices for APEC. Peterson Institute for International Economics. Policy Brief No. PB09-16. July.

Bhagwati, J. Free Trade Today. Princeton, NJ: Princeton University Press.

Breslin, S., and R. Higgott. 2000. Studying Regions: Assessing the New, Learning from the Old. New Political Economy 5(3) November: 333-353.

Brown, D.K., A.V. Deardorff, and R.M. Stern. eds. CGE Modeling and Analysis of Multilateral and Regional Negotiating Options (Working Paper). to be published in R.M. Stern (ed.). Issues and Options for US-Japan Trade Policies. University of Michigan Press. Ann Arbor. Forthcoming.

Cheong, Inkyo.

2002. Korea's FTA Strategies. KIEP Report.

2005. Evaluation of Recent Progress of FTAs in East Asia - a Korean perspective from East Asian Economic Regionalism - Feasibilities and Challenges. co-edited by Choong Yong Ahn and Richard E. Baldwin. Springer.

Dent, Christopher M. 2008. East Asian Regionalism. Routledge.

Findley, C. 2000. Old Issues in New Regionalism. Presented at the 2000 APEC Economic Outlook Symposium. Manila, Philippines. July.

Garnaut, R. 1996. Open Regionalism and Trade Liberalization: An Asia-Pacific Contribution to the World Trade System. Institute of Southeast Asian Studies:p. $1-41$

IMF Asia and Pacific Department. 2008. Intra-regional Trade Key to Asia’s Export Boom. Asian Exports. IMF Magazine. February.

Kawai, M., and Ganeshan Wignaraja.

2007. ASEAN+3 or ASEAN+6: Which Way Forward?. Asian Development Bank Institute Discussion Paper No. 77.

2008. Regionalism as an Engine of Multilateralism: a Case for a Single East Asian FTA. Asian Development Bank. Working Paper Series on Regional Economic Integration No. 14. February.

Kim, C. 2003. Towards an East Asian Free Trade Agreement. presented at the JEF/SIIA International Symposium. Singapore. March 7-8.

Kwon, Youngmin. 2002. Regional Community-building in East Asia. Yonsei University Press.

Lee, Chang Jae and Jeong, Hyung-Gon. 2006. From East Asian FTAs to an EAFTA. KIEP. Policy Analysis 06-01. December.

Lee, Min Ha. 2009. ASEAN+3, ASEAN+6, or APEC FTA for EAST Asia? - CGE Model Analysis. Master's Thesis from Graduate School of International Studies. Seoul National University.

Nam, S. 2000. APEC Trade Liberalization after EVSL. KIEP APEC Study Series 00-07.

OECD. 2005. Regional Integration in the Asia Pacific: Issues and Prospects. the Bob 
Hawke Prime Ministerial Center at the University of South Australia.

Wonnacott, R. 1996. Trade and Investment in a Hub-and-Spoke System versus a Free Trade Area. World Economy19:237-52.

Yip, Wei Kiat. 2001. Prospects for Closer Economic Integration in East Asia. Greater East Asia. Stanford Journal of East Asian Affairs 1:106-111. Spring.

Yue, Chia Siow. 2007. Challenges and Configurations of a Region-wide FTA in East Asia.

Singapore Institute of International Affairs. Presented at the FONDAD

Conference. Kuala Lumpur. August.

Websites

Official FTA homepages

APEC: http://www.apec.org/

ASEAN: http://www.aseansec.org/

Australia: http://www.dfat.gov.au/trade/ftas.html

EU: http://europa.eu/pol/comm/index_en.htm

India: http://exim.indiamart.com/free-trade-agreement/

Japan: http://www.mofa.go.jp/policy/economy/fta/

Korea: http://www.fta.go.kr/user/index.asp

New Zealand: http://www.mfat.govt.nz/Trade-and-Economic-Relations/

US: http://www.export.gov/fta/

World: http://www.wto.org/english.tratop_e/region_e/region_e.htm (WTO)

Official Statistical Data Banks

Korea: http://www.bok.or.kr/ (Bank of Korea)

http://www.kita.net (KITA)

http://www.nso.go.kr/ (Korea National Statistical Office)

US: $\quad$ http://www.bea.gov/index.htm (Department of Commerce)

World: http://www.imf.org/external/data.htm (IMF)

http://comtrade.un.org/db/default.aspx (UN Comtrade)

http://www.worldbank/org/ (World Bank) 


\section{Appendix: Data Aggregation}

The database adopted for CGE model analysis in this research were both GTAP 6 (March 2005) and GTAP 7 (August 2009). The aggregated database created by Limited (10x10, V7) GTAPAgg Licence program contained following key features:

\begin{tabular}{|c|c|}
\hline & Contents of GTAP 6 Aggregation \\
\hline Region & $\begin{array}{l}\text { Korea, China, Japan, ASEAN (Indonesia, Malaysia, Philippines, Singapore, Thailand, } \\
\text { Vietnam and Rest of Southeast Asia), Austland (Australia and New Zealand), India, } \\
\text { USA, O_APEC (Canada, Chile, Mexico, Peru and Russia), EU (Austria, Belgium, } \\
\text { Bulgaria, Cyprus, Czech Republic, Denmark, Estonia, Finland, France, Germany, } \\
\text { Greece, Hungary, Ireland, Italy, Latvia, Lithuania, Luxembourg, Malta, Netherlands, } \\
\text { Poland, Portugal, Romania, Slovakia, Slovenia, Spain, Sweden and UK) and the Rest of } \\
\text { World }\end{array}$ \\
\hline Sector & $\begin{array}{l}\text { Primary, Resources, Light Manufacturing, Heavy Manufacturing, Automobiles \& Parts, } \\
\text { Services }\end{array}$ \\
\hline \multirow[t]{2}{*}{ Factor } & Land, Unskilled Labor, Skilled Labor, Capital, Natural Resources \\
\hline & Contents of GTAP 7 Aggregation \\
\hline Region & $\begin{array}{l}\text { Korea, China, Japan, ASEAN (Indonesia, Malaysia, Philippines, Singapore, Thailand, } \\
\text { Vietnam and Rest of Southeast Asia), AustNZ (Australia and New Zealand), India, USA, } \\
\text { O_APEC (Canada, Chile, Mexico, Peru and Russia), EU (Austria, Belgium, Bulgaria, } \\
\text { Cyprus, Czech Republic, Denmark, Estonia, Finland, France, Germany, Greece, } \\
\text { Hungary, Ireland, Italy, Latvia, Lithuania, Luxembourg, Malta, Netherlands, Poland, } \\
\text { Portugal, Romania, Slovakia, Slovenia, Spain, Sweden and UK) and the Rest of World }\end{array}$ \\
\hline Sector & $\begin{array}{l}\text { Primary, Steel-Metal, Electronic goods, Trans-goods, Machinery, Other Manufacturing } \\
\text { and Services }\end{array}$ \\
\hline Factor & Land, Unskilled Labor, Skilled Labor, Capital, Natural Resources \\
\hline
\end{tabular}

On designing each initial model, the qualities of FTAs in establishing subject trading blocs were assumed to be high with respect to the trade liberalization. The developed models from version 6 were then solved with Gragg: 2-4-6 steps extrapolation with automatic accuracy of sub-intervals 2, while that from version 7 were solved with Johansen 1-step to provide economic impacts of trading bloc on each designated region. Furthermore, the same level of trade liberalization was assumed at the same ' $0 \%$ ' target rate for all sectors for both the KORUS and Korea-EU FTAs. Again, the Gragg solution method and Johansen solution method for versions 6 and 7 respectively were employed to verify the effects on each scenario in which either or both the KORUS and Korea-EU FTA were imposed upon the each basic East Asian trading bloc. 